\title{
Confederacy - the polish new right wing between tradition and modernity
}

\section{Konfederacja - polska nowa prawica między tradycją a nowoczesnością}

Jarosław Tomasiewicz ${ }^{*}$

\begin{abstract}
Konfederacja Wolność i Niepodległość (Confederacy for Freedom and Independence) is new, far-right force in Poland. Success of the KWiN broke political monopoly of the Prawo i Sprawiedliwość (Law and Justice) party on the right wing. The paper examines structure, strategy, ideology and social basis of the Confederacy. This new formation amalgamating cultural conservatism and economic liberalism is similar rather to American Trumpism and alt-right than the protest movements of WesternEuropean right wing populism.
\end{abstract}

Key words: Confederacy for Freedom and Independence, populism, conservatism, far-right, alt-right

\begin{abstract}
Abstrakt
Konfederacja Wolność i Niepodległość jest nową siłą na polskiej scenie politycznej, sytuującą się na radykalnej prawicy. Sukces KWiN przełamał długotrwały monopol Prawa i Sprawiedliwości na prawicy. Artykuł analizuje strukturę organizacyjną, strategię, ideologię i bazę społeczną Konfederacji. Nowa formacja łącząc kulturowy konserwatyzm z ekonomicznym liberalizmem przypomina raczej fenomen Trumpa i amerykańskiej alt-right, niż prawicowo-populistyczne ruchy protestu w Europie Zachodniej.
\end{abstract}

Słowa kluczowe: Konfederacja Wolność i Niepodległość, populizm, konserwatyzm, skrajna prawica, nowa prawica

* Institute of History, University of Silesia in Katowice (jaroslaw.tomasiewicz@us.edu.pl); https://orcid.org/0000-0001-9750-5256. 


\section{Introduction}

The anti-system right wing during the Third Republic of Poland remained on the political fringe (apart from the parliamentary presence of Liga Polskich Rodzin - the League of Polish Families - in 2001-2007), which was in sharp contrast to the power of its pre-war counterpart. The reasons for this state of affairs, as I demonstrated in my work "Ugrupowania neoendeckie w Trzeciej Rzeczypospolitej", lay in the anachronism of doctrine and program, dug up right from the interwar period (Tomasiewicz, 2003: 365-367). The modern radical right, however, has undergone a transformation and modernization, which fuelled its expansion. The aim of this paper is to investigate the circumstances that allowed the Confederacy for Freedom and Independence to succeed.

The author will attempt to answer the questions about: / $1 /$ the genesis of the Confederacy, / 2 / its structure, / 3 / strategy and tactics, / 4 / ideology and program, / 5 / social base. The hypothesis which will be verified is that the shape of the present embodiment of the Polish radical right is a product of its historical traditions and contemporary social context. The analysis will be based on media coverage created by the political environment associated with the KWiN. Established in 2019, the Confederacy is so recent phenomenon that there are no scientific studies to be cross-checked at the time of submitting the text.

\section{Origins}

The Confederacy for Freedom and Independence is a new political group, but it is deeply rooted in the history of the Third Republic of Poland. The inception of this formation is very complicated, but a brief sketch of it is necessary to understand its character. The Confederacy was created out of the intertwining of two different political trends: conservative-liberal and national-democratic.

The movement describing itself as "conservative-liberal" is in fact a transfer of American paleolibertarianism to Poland. It has only loose ties with Polish conservative traditions, but it can be hypothesized that it arises from the individualistic psychology of native Sarmatism. Janusz Korwin-Mikke has been the flagship figure of this movement for many years. In 1987, he founded the Real Politics Movement, which gave rise to the Real Politics Union party (Unia Polityki Realnej). For decades, the UPR languished on the margins of Polish politics, treated in terms of political folklore (the best result: 3.2\% in 1993) (Unia: 165-166; B.S. 1996: 55-58; B.S. 2000: 33-38). The lack of success resulted in dissention, and finally, in 2009, the founder left the UPR, creating the Wolność 
i Praworządność party (Freedom and Rule of Law) (soon transformed into the Kongres Nowej Prawicy (New Right Congress)). In 2015, Korwin-Mikke lost the chairmanship of the KNP, to which he reacted by creating the Koalicję Odnowy Rzeczypospolitej Wolność i Nadzieja (Coalition for the Renewal of the Republic of Poland, Freedom and Hope - temporarily using the name Freedom). The election results showed that the strength of "conservative liberalism" was the eccentric personality of Korwin-Mikke; the marginalized UPR was first associated with the National Movement, and then - similarly to the KNP - with the Kukiz'15 formation (B.K.-G., 2017: 126-132; A.P. 2017: 133-134).

The National Democratic movement revived disintegrated after 1989: its moderate wing was represented by Zjednoczenie Chrześcijańsko-Narodowe (Christian-National Union), while the orthodox wing was represented by a few conflicted National Parties. In 2001, as a result of the consolidation of orthodox groups, the Liga Polskich Rodzin (League of Polish Families) was established, the youth branch of which was Młodzież Wszechpolska (Tomasiewicz, 2002). The LPR under the leadership of Roman Giertych achieved significant success (7.87\% in 2001) and participated in the government of Jarosław Kaczyński in 2006 - 2007, but the 2007 elections wiped it out of the political scene (K.Z., 2017: 163). The Młodzież Wszechpolska (All-Polish Youth) had gained independence earlier, with which the authorities of the parent party had severed relations as part of Giertych's policy of improving the image of the LPR (Młodziez Wszechpolska: zerwanie). However, the All-Polish Youth managed to survive, and this break-up led to a permanent break with the older generation of National Democrats. MW, on the other hand, started cooperation with Obóz NarodowoRadykalny - a political camp formed on the basis of local skinhead groups (more about ONR: Tomasiewicz, 2010). The March of Independence, initiated by the ONR in 2006, became a joint action of both organizations. The march, expressing the dissatisfaction of the youth community (including football fans) with the PO government, grew in strength from year to year (Szymanik, 2012).

Young nationalists decided to capitalize on the success of the Independence March. On November 11, 2012, a coalition of nationalist as well as conservativeliberal social organizations and political groups was established under the name of the Ruch Narodowy (National Movement), which on December 10, 2014 was transformed into a political party. After so-called Holochergate (disclosure of the confidential correspondence of the ONR leader Przemysław Holocher) in 2013, the leadership of the National Movement was in fact dominated by the MW headed by Robert Winnicki (Baliszewski, 2013; cf. Index). Spectacular failures in the 2014-15 European, local government and presidential elections prompted nationalists to conclude an election alliance with Kukiz'15 (List). This decision was the reason for a split — the ONR withdrew from the National Movement, and the group of Marian Kowalski (Narodowcy RP - the National Democrats of the Republic of Poland) (Powstaje) has also left. From the Kukiz's 
list, the nationalists introduced 5 deputies. However, when Winnicki tried to form a group of the National Movement in April 2016, it turned out that he was left alone - his colleagues founded an association of the National Democrats that competed with the National Movement and remained in the Kukiz'15 club or evolved towards the PiS (Reorganization).

A long series of failures prompted these two forces on the far right of the Poland's party system - nationalists and conservative liberals - to conclude an alliance. It was not an easy decision, as the contractors were critical of each other: Korwin-Mikke often accused nationalists of "socialism" and tried to organize a competitive independence march on October 7 (Korwin-Mikke, 2012), Winnicki replied that Korwin was not a serious politician (Winnicki, 2012). The Kukiz'15 breakdown, however, opened the door to action. On December 6, 2018, the KORWiN and the RN announced the formation of a coalition (Ruch Narodowy $i$ Wolność), which in January 2019 was joined by the associations "Pobudka" of Grzegorz Braun and Skuteczni of Piotr Marzec, and the pro-life community represented by Kaja Godek (Czuma, 2019). The formation created in this way initially used the name of the Koalicja Propolska, but on February 27, 2019, it identified itself as the confederacy of KORWiN Braun Liroy Narodowcy (Konfederacja KORWIN Braun Liroy Narodowcy łaczy). In March, a parliamentary group of the Confederacy was formed (Winnicki, Marzec, Jacek Wilk, Robert Kulesza and Marek Jakubiak, then also Paweł Skutecki, temporarily Robert Majka) (W Sejmie; Nowy poset; Poset Robert).

\section{Structure}

The way the Confederacy is organized reflects its complicated origins. Initially, it was a coalition of a number of entities - apart from those mentioned, there was also the Federation for the Republic of Poland of Marek Jakubiak (Sensacyjna), Eastern Borderland circles represented, among others by Władysław Osadczy and Andrzej Zapałowski (Konfederacja KORWiN Braun Liroy Narodowcy powiększa), some regional structures of Kukiz'15 (e.g., in Silesia) (Działacze; Kandydat), the Party of Drivers and the Polish Association of Knowledge about Vaccinations (Lewicki, 2019). The defeat in the May European elections meant that a month later Jakubiak and Marzec (Federation of JakubiakLiroy) (Rozłam; cf. Federacja; Głos) left the coalition, and Godek in August (Trzy). On the other hand, the Union of Christian Families (Kolejna partia), agricultural circles (Wojciech Mojzesowicz and Krzysztof Tołwiński) (Pokora-Kalinowska, 2019) and the National League (founded by former activists of the LPR and Samoobrona) joined the coalition. On July 26, 2019, a political party called 
Konfederacja Wolność i Niepodległość was registered, which ensured inclusion in the polls, facilitated access to the media and opened the way to an election subsidy (\#KONFEDERACJA zarejestrowana)

The new party is federal. As Bosak said, "it is based on two experienced party structures, the KORWiN party and the National Movement, the third is being built" (Bosak, 2019). The third important component is the Konfederacja Korony Polskiej (Confederacy of Polish Crown) - a party of Catholic Integrists founded in September 2019 by Braun (Wystartowata). The three-fold structure of KWiN is reflected in the composition of the parliamentary group: five Korwinists (Korwin-Mikke, Konrad Szczepan Berkowicz, Artur Erwin Dziambor, Jakub Kulesza, Dobromir Sośnierz), five nationalists (Bosak, Krystian Kamiński, Krzysztof Tuduj, Michał Piotr Urbaniak, Winnicki) and a "traditionalist" Braun (Nacjonaliści). The discrepancies within it appeared so deep that Korwin-Mikke initially planned to divide it into two separate parliamentary groups - national and libertarian (Konfederacja ostatecznie). Ultimately, there was one group, whose chairman was Kulesza and Bosak became a vice-chairman and spokesman (Pierwsze).

An analyst sympathizing with the Confederacy attempted to determine the strength of individual political trends on the basis of votes cast in the European elections. According to these calculations, the candidates for KORWiN received $49.8 \%$ of the votes, RN $22.9 \%$, Skuteczni $6.5 \%$, FdR $6.3 \%$, Braun $5.3 \%$, antivaccineers $3.7 \%$, pro-life 3, 5\%, Drivers $1.9 \%$ (although one can have reservations about the methodology, this analysis roughly corresponds to the ratio of forces between Korwin's supporters and nationalists in earlier polls of voting preferences) (Lewicki, 2019). However, it should be remembered that the situation is even more complicated, as the National Movement itself was created as an amalgamation of several dozen of groups of very different nature. ${ }^{1}$

1 These were: Młodzież Wszechpolska, Obóz Narodowo-Radykalny, Związek Żołnierzy Narodowych Sił Zbrojnych, Stowarzyszenie Marsz Niepodległości, UPR, Ruch Wolności, Fundacja im. Bolesława Chrobrego, Grupy Rekonstrukcji Historycznych Narodowych Sił Zbrojnych, „Myśl.pl”, Fundacja Inicjatyw Polskich, „Polityka Narodowa”, Towarzystwo Wszechpolskie „Sztafeta”, Klub Narodowej Myśli Politycznej „Votum”, Kobiety dla Narodu, Ruch Narodowy - Sekcja Kobiet, Stowarzyszenie na Rzecz Tradycji i Kultury „Niklot”, Akademicki Klub Myśli Społeczno-Politycznych „Vade Mecum”, Fundacja „Optima”, Fundacja Dziedzictwa Narodowego, „Magna Polonia”, Narodowcy.net, Stowarzyszenie „Przymierze Narodu”, Stowarzyszenie „Fides et Ratio”, Instytut im. Romana Rybarskiego, Towarzystwo Torunium im. Antoniego Bolta, Stowarzyszenie „Dolina Sanu”, Stowarzyszenie „Duma i Nowoczesność”, Katolickie Stowarzyszenie „Civitas Christiana” Kraków, Stowarzyszenie „Stop Korupcji”, Katolicki Klub im. św. Wojciecha, Towarzystwo Gimnastyczne „Sokół” w Lublinie, Wielkopolscy Patrioci, Narodowy Koszalin, Dębiccy Patrioci, Narodowa Łódź, ONR Podhale, Patriae Fidelis (the United Kingdom). Ruch Narodowy. The neo-pagan "Niklot" and the "Duma i Nowoczesność" associated with neo-Nazis draw attention in this group. 
From the very beginning, the Confederacy focused on building a "broad anti-system movement" while maintaining the ideological identity of its components. The KWiN leaders are aware of the heterogeneity of the formation. Bosak said "We are not a single leader movement, none of us says what to say on command, none of us thinks on command," (Szymański, 2019). He admitted that "it will be necessary to talk to each other, establish a position, on the one hand, respecting differences of opinion, which of course exist, and on the other, look for common points that are possible to be found" (Bosak, 2019). This internal pluralism is even presented as an asset because - according to Wilk "each of our voters will easily find a candidate who is very close to them in their worldview" (Wilk, 2019).

Nevertheless, the Confederacy remains internally incoherent. Factional infighting emerged during the primary election. "Wolnościowcy" (Libertarians) put forward as many as four candidates (K. Berkowicz, A. Dziambor, J. KorwinMikke, J. Wilk) intending to support the strongest of them in the last phase. However, when it turned out that in minority but disciplined nationalists managed to recruit the largest number of electors for their candidate Bosak, Korwin's supporters decided to back Braun instead of - according to the agreement - Dziambor. As a result, the Dzambor's supporters threw their votes to Bosak, ensuring him victory (Sitnicka, 2020). Bosak, who based his campaign on economic issues, provided the Confederacy with program consistency. ${ }^{2}$ Disagreements, however, still appear, at least on the tactic level - as it seems, "libertarians" are more ill-disposed towards to PiS (Polityk).

\section{Strategy and tactics}

The KWiN positions itself in opposition to all other political forces (so-called "gang of four:" PiS, PO, PSL, SLD). Paradoxically, it pays the least attention to the opponent who is ideologically most distant, i.e., the left wing, although the party sees the main enemy in "cultural Marxism" (Bosak, 2019) and its goal is "to stop comrades of Biedroń and Czarzasty" (Winnicki ostro: "Polacy). In principle, the KWiN equally rejects the possibility of cooperation with the Koalicja Obywatelska (Civic Coalition) (despite the conciliatory gesture made by Sławomir Neumann after the elections) (Winnicki odpowiada). In relation to the Law and Justice, the attitude of KWiN was more balanced. On the one hand,

${ }^{2}$ Warcholiński, Tomanek 2020. At this point, it is worth giving consideration to the evolution of the socio-economic views of Bosak, who in 2017 was the "economic centrist" (the ratio of "equality" to "market": 50.6:49.4). Nowak 2020 
the PiS was attacked as a pseudo-right-wing and pseudo-patriotic political party that deceived its voters ("Marxists are not only our enemy. Our enemy is the so-called right wing, which is in agreement with big business," Bosak called) (Naszym; see Fenomenalny; Winnicki ostro o Sakiewiczu; \#Konfederacja proponuje). On the other, however, the United Right was assessed better than the liberal-left opposition (Skupień, 2019) and the possibility of conditional cooperation was allowed (Dziambor: "There are many projects in which we can support the government. These include ideological matters in which we share a similar opinion") (Dziambor; cf. Winnicki o warunkach). They even declared readiness to accept right-wing PiS politicians (Krystyna). The only political party with which an alliance was allowed in July 2019 was Kukiz'15, but the leader of this formation being in conflict with the Korwin supporters chose the PSL (Konfedracja i Kukiz'15).

The KWiN leaders are aware of the fact that they compete with the PiS for the right-wing electorate (which was openly admitted by Sławomir Mentzen) (Fenomenalny). This prompts them to present themselves as a more radical and consistent version of PiS, not questioning the ideological foundations of the United Right and open to dialogue (such a line was prompted to the confederates by Rafał Ziemkiewicz before the break-up took place) (Ziemkiewicz; cf. Robert). "We are a Catholic-national remorse for the PIS," said Tuduj (Tuduj, 2019). A different concept is promoted by Adam Wielomski, who says that "The Confederacy must remain in opposition no matter what, because Kaczyński will drain it out as he once did with the LPR and Samoobrona" (Wielomski, 2019d). He demands that "in the minds of voters, we carefully demote our [...] ideological world from PiS." 3 This resonates with the postulate of Tomasz Kalinowski that the KWiN should create its own institutional infrastructure enabling permanent rooting in the social background, because "otherwise we will have the same end as Kukiz'15" (Kalinowski, 2019b).

While the strategic line of KWiN is not yet finally clarified, the tactics can be assessed as well-thought-out and consistent. Considering the genesis of the Confederacy as an electoral alliance, it is not surprising that its actions oscillated around elections. The challenge was to collect signatures necessary to register the electoral roll, which was successfully carried out (Konfedracja ogólnopolskim). Some effort was taken to make the candidates' presentations a media spectacle, introducing such people as a Miss World runner-up Roksana Oraniec (Kandydatka). The priorities emphasized in the campaign were defined on the basis of focus research of the potential electorate (Fenomenalny). Postulates were publicized with the help of various types of actions, the most important

${ }^{3}$ Wielomski 2019a. His wife (and the candidate of KWiN) Magdalena Ziętek-Wielomska even considers the division into left- and right-wing to be secondary and irrelevant (ZiętekWielomska, 2019). 
criterion of which was media coverage, i.e., the content carrying capacity and the spectacular form.

The main task of the Confederacy was to break through to the public with the name and program. The desire to attract media attention was also behind other actions of KWiN: lawsuits against the media (Godek, 2019b; Telewizja; Poczatek), disclosure of recordings from ARiMA (Minister), participation in debates (Skandal!; Dzisiaj; Debata), "happenings" such as Konrad Berkowicz with a kippah (Piotr) or Wilk with a flag (Pracownicy). Intra-party events such as the National Women's Congress in May (Narodowy) or the election convention in September - were strived for to make them more attractive in the media; as Bosak said, "We should perfect their formula so that they are not a rigid academic lecture, but a show" (Krzysztof Bosak podsumowuje). The faint echo of KWiN's voice reverberated in the parliament due to the small size of the parliamentary group. Nevertheless, one can note here, e.g., the formulation of a motion to dismiss the Ombudsman (Konfedracja sktada) or the recognition of the last session of the Sejm of the 8th term as illegal (Szok!). The street activity played a greater role, above all the demonstrations: the March of Sovereignty on May 1 (Marsz) and the March against Jewish claims on May 11 (Dziesiatki) in Warsaw, the Normality March in Bydgoszcz (Setki), the happening "Spring wind rips the flags of the European Union" (Wiosenny) and others (e.g., Rzeszów).

The problem of KWiN remains, however, the boycott by the majority of the media - both pro-government and opposition (Krzysztof Bosak podsumowuje; cf. Czerwona; Cenzura). Attempts were made to avoid this obstacle by expanding the Internet media system, including the portals Media Narodowe, wRealu24, eMisja, wPrawo (Bosak: "Media). As a party supporter wrote: "The Confederacy communicates with its electorate exclusively via the Internet, social media, and Internet television. The party created a cheap and decentralized media network independent of the regime, a social communication network" (Prof. Wielomski). A large role was attached to social media (Kampania), complaining about the blockade from Facebook (Kolejna blokada). Attempts were made to use advertising spots and music to the maximum (e.g., Nowy spot). Nevertheless, Winnicki lamented: "We have a huge problem with communicating with elderly people who do not use the Internet. This is the result of a TV blockade"( $R$. Winnicki).

Task number two, in turn, was to consolidate and mobilize voters, for example, the campaign \# NieDlaRoszczen consisting in collecting signatures on a letter to Donald Trump (Cejrowski). This was also, as it seems, the genesis of the project of presidential primary elections in the Confederacy, which on the one hand, are to activate the potential electorate, and on the other, to attract the attention of the media (Konfederacja organizuje; Korwin, Braun). The Confederacy also tried to take up local issues (such as in Pruchnik or Szczecin) (Konfederacja broni; Szczecin) in order to reach the inhabitants of the outlying regions. 
In the presidential campaign, the main target of the Confederacy became small businesses frustrated by economic restrictions related to the COVID-19 pandemic. Bosak, as a candidate of the Confederacy, adapted to the requirements of conservative-liberal voters, taking care of the image of a well-balanced technocrat. For example, he spoke more about water management, than about property claims by Jewish organizations (Krzysztof Bosak: musimy), he avoided verbal aggression (e.g., he described the A. Duda's attack on the "LGBT ideology" as "a kind of provocation" and cynicism) (Krzysztof Bosak : jestem), he took exceptional care of his impeccable image (a characteristic fragment about clothes in an interview with Robert Mazurek on RMF) (Bosak: Wiara).

\section{Ideology and program}

The Confederacy does not have a uniform ideology or a coherent view of the world. Although Wielomski promotes the concept of "national liberalism" or "market nationalism" (Wielomski, 2019b), in practice it remains in the sphere of distant forecasts (if not pious wishes). Some refer to conservative liberalism (Wilk, 2019), others to Dmowski's doctrine (Ziętek-Wielomska, 2019). When one of the candidates put forward in the election says "I am a libertarian, not a conservative" (Bartyzel, 2019), the other replies: "I define my views as national, conservative, deeply anti-liberal" (Smuniewski, 2019). For some, the model is the right wing of the US Republican Party (Konfederacja zaprezentowata), for others the National Front of Jean-Marie Le Pen (Konwencja wyborcza). "Let's not delude ourselves [...] that libertarians and nationalists are groups that can be dovetailed with each other - this is not the case," says one of the female candidates of KWiN (Trela, 2019). Most of all, a negative program - a common enemy - brings them together. "We don't want Jews, homosexuals, abortions, taxes and the European Union!" - Mentzen announced (Fenomenalny). Islamists and "leftists" should be added to this list too.

One of the most important positive values uniting the Confederates is the sovereign state. For most, the ideal is the national state - the political organization of the Polish nation (Ziętek-Wielomska, 2019) — but there are also those who refer to the Jagiellonian tradition of a multinational state (Sajna, 2019) and contrast "extreme nationalism" with a "sober national attitude" (Drozdowski, 2019). The principle of the nation state, in which "almost all inhabitants constitute one nation" (Trela, 2019), results in the resistance of KWiN to immigration, the criticism of which is used against the PiS government. "We will stop the flood of immigrants from Ukraine and Asia," Winnicki called (Konwencja wyborcza), "We must stop this madness!" (Winnicki o stowach). "National secu- 
rity means a responsible migration policy. Stop migration!" added Tumanowicz (Konwencja). However, even in this matter, the KWiN did not develop a uniform position. As an alternative solution, "an immigration filter that eliminates the influx of people who threaten security, culture and social norms, but also leaves the door open for those migrants who want to work for the benefit of Polish economic development" (Bartyzel 2019; cf Ekonomiczny). One of the candidates even put up Qatar as a role model, "in which the native Qataris have many benefits, and the main workforce is immigrants from other countries" (Sajna, 2019).

The second pillar of the Confederate worldview is religion. The role of Catholicism, however, is understood very differently - when some activists (mainly Braun's supporters and nationalists) stand in the position of Catholic Integrism, for most libertarians, Christianity is only an element of the cultural tradition. Krzysztof Szymański from the National Movement is a representative of the former group, who says: "The only way to ensure God's order in Poland is to return Catholic entities to their ideological foundations, articulate an uncompromising, Catholic program [...], and above all, give oneself and all activities to the Immaculate Heart of Mary, Queen of Poland!" (Szymański, 2019).

Other nationalist, Michał Wawer, demands to prosecute the blasphemy (Wawer, 2019). On the other hand, Cyprian Sajna emphasizes his commitment to the secular nature of the state, and writes that in the KWiN "there is a place for atheists, dissenters, and free-thinkers," he points out that Korwin-Mikke "cannot be viewed as a Catholic model" (Sajna, 2019). In the ranks of the Confederacy there was initially even a former activist of the Palikot Movement, Jacek Władysław Bartyzel, known for his anti-clerical happenings, who declared himself "an unbelieving but patriotic liberal" (Bartyzel 2019; cf. Szydzit).

Despite the ambivalent attitude towards religion, the KWiN unanimously proclaims an extremely conservative cultural program. It primarily means support for the traditional family model (Trela, 2019), although there are attempts among nationalists to find an answer to the challenge of feminism (Bryłka, 2019). The defense of the family takes shape primarily in the form of a fight against the LGBT ideology (Partia_KORWiN 2019), in which the Confederacy is trying to outbid the PiS (Konfederacja ostro o Emilewicz). Confederates drafted a bill forbidding the promotion of homosexual attitudes and blocked parades of equality (Konfederacja obiecuje), Korwin said that "All those elites that support deviations must be slaughtered" (Korwin ostro), and Godek that "pederasty is the introduction to pedophilia." "However, one can also (less often though) come across voices stressing that "this what concerns those two people and only them should be subject to the rules of freedom" (Bartyzel, 2019) and Sośnierz joined the working party for LGBT equality (Poset Konfederacji). The KWiN

\footnotetext{
${ }^{4}$ GodekKaja, 2019a. Braun even spoke of "penalizing homosexuality." Wielomski, 2019c
} 
also raises the postulate of an absolute ban on abortion in order to distinguish it from the compromise policy of the United Right (Prezes Trybunatu).

Apart from the national-religious Tradition, the idea of Freedom is a component of the KWiN ideology. While in the symbolic sphere, jingoistic traditionalism prevails, the influence of liberal and anti-statist solutions is visible in a number of program proposals. In the field of education, this means the development of home education (Mentzen, 2019) and the educational and cultural voucher, shifting the focus to the family (Wieczorek, 2019). In terms of security, the Confederacy proposes to facilitate citizens' access to weapons and shooting training (Polska dla).

The liberal element stamped its imprint on the KWiN's economic agenda the strongest. According to Wilk, "there is a need to create the best conditions for the development of Polish business, [and] the government as well as officials should interfere as little as possible with the growth and enrichment of domestic enterprises, especially family ones" (Wilk, 2019). Characteristically, the Bosak presidential program - as the only one - received a positive assessment of ING Bank Śląski experts in terms of fiscal balance (Benecki, Kasek, 2020). Confederates agree in the pursuit of deregulation limiting the influence of the state on the economy. "As much of the state as it is necessary, as much freedom as it is possible," says Mentzen (Mentzen, 2019). They prepared, modeled on the so-called the Wilczek Act, "Polish Entrepreneur Package" containing, among others, Act on small scale street trading (Polska dla). Nevertheless, a limited participation of the state in economic life (e.g., arms industry, critical infrastructure) is allowed (Bala, 2019). To quote Mentzen once more "in the 21st century, the free market is the right answer less often than I would like, but still much more often than the statists would like" (Mentzen, 2019).

In addition to eliminating bureaucratic barriers, the activity of Polish entrepreneurs is to be facilitated by a significant reduction and simplification of taxes. Income tax would be completely abolished (" 1000 plus for every working person. We will stop punishing Poles for working!") (Takiej), the tax system would be based on VAT (Mentzen 2019). Social security contributions would be voluntary (Takiej).

The savings necessary in view of reducing the state's income were to be sought by KWiN in reducing social expenditure. The Confederacy criticizes the "irresponsible policy of living at the expense of future generations" (Szymański, 2019). Criticism also applies to the "500+" program - as an alternative formula of a policy to boost the birth rate, progressive tax breaks for children are proposed, and a zero VAT rate for products purchased in relation to bringing up children (Skupien, 2019). At the same time, however, the confederates recognize the need to maintain certain elements of social policy (Drozdowski, 2019a), noticeably in the national wing of KWiN, the so-called "national solidarists" (Łobodzinski, 2019). 
Confederates do not make secret of their discrepancies on economic issues (according to Mentzen, "the subject of economy is something I do not fully agree with, but we do not have to be unanimous on every issue," says the candidate) (Trela, 2019). Nationalists present protectionist views, sometimes they are close to the idea of the "third way" (Sowiński, 2019). According to Wilk, however, "In fact, the only significant difference concerns the assessment of foreign capital. Nationalists claim that capital has nationality, we - libertarians - that it has interests" (Wilk, 2019).

Economic liberalism does not go hand in hand with political liberalism. The KWiN is the only major political party in which criticism of democracy is articulated. Dominik Cwikła (an editor of the nczas.com website) writes, for example, that in a democratic system "one cannot [...] create something unambiguously good, just and good, because [...] the 'people' [...] are [...] mostly the rabble" (Cwikła, 2019; cf. Wystartowała). Sympathies for the monarchy are openly articulated (Sajna, 2019; cf. Wilk, 2019). Democracy is treated not as a value but at best as an objective reality (Drozdowski, 2019a). However, the practical systemic proposals of KWiN are an inconsistent mixture of authoritarian postulates (increasing penalties, including the reintroduction of the death penalty) (Mentzen, 2019) and libertarian demands (liquidation of public media, limiting the powers of law enforcement agencies) (Liroy; Dość; Liderzy). In addition, the Confederacy proposes to streamline the state through the parameterization of the work of courts and prosecutor's offices, as well as the introduction of e-voting (Konfederacja zapowiada; Polska dla).

The Confederacy is trying to work out an alternative program of foreign policy. Its main distinguishing feature is to be "multidirectional policy." "A multidirectional policy is a basic postulate [...] in the field of foreign policy. That is, fragmented cooperation with various powers without a clear and permanent focus on one country," said Tuduj (Tuduj, 2019; cf. Wilk, 2019). In practice, this would mean a dramatic shift in Poland's foreign policy.

The idea of a sovereign state conflicts the Confederates with the European Union (Młodzież Wszechpolska pocięła). Korwin-Mikke stated: "We have only one joint point (of our program), but a strong one - 'to hell with the Union' (Ruch Narodowy $i$ Wolność). The allegations against the EU are threefold - it is perceived as a tool of Germany (a threat to national interests), a carrier of "cultural Marxism" (a threat to Latin civilization), and a bureaucratic behemoth (a threat to civil and economic freedom) (Prezes Ruchu; cf. Ziętek-Wielomska, 2019; Wawer, 2019; Tuduj, 2019). The last aspect draws attention to the negative effects of EU regulations on the Poland's energy sector (climate commitments) and agriculture (Wilk, 2019; Konfederacja: Nie), and warnings were issued against adopting the common currency (Konfederacja zaprezentowała; Konfederacja odpowiada). 
Nevertheless, the Confederates make it clear that they are "union skeptics" and not euroskeptics (Kalinowski, 2019a). "We are not against Europe and its great civilizational heritage," said Tuduj (Tuduj, 2019), "We are, we were and we will be in Europe" (Wiceprezes). They identify themselves with the idea of "Europe of free nations and nation states" (Tuduj, 2019). However, this idea is vague. The radical wing (mainly — but not only — nationalists) wants "Polexit," although they intend to keep Poland in the Schengen area and the European Economic Area (Konfederacja: Wyprowadzimy; cf. Wiceprezes). The moderate wing considers it unrealistic and pointless, proposing instead the slogan of "return to the roots of Robert Schuman's United Europe" (Drozdowski, 2019b), which supposed to mean a profound reform of the EU, dismantling the "bureaucratic superstructure" (Dziambor, 2019; cf. Bartyzel, 2019).

At the same time, the Confederacy clearly distances itself from the USA. Bosak criticized "servile subordination to America" (Krzysztof Bosak: rzad), he said that "Poland did not get up from its knees, but only changed the kneeler from the EU to the USA" (Polska nie). Korwin-Mikke accuses PiS of being an "American agency" (Korwin-Mikke: PiS jest; cf. Korwin-Mikke: PiS zależy; Marciniuk, 2019). Polish-American relations are considered unequal and unfavorable for Poland (e.g., the issue of digital tax) (Krzysztof Bosak: rzad; Konfederacja ostro o wpisach), the United States is considered an uncertain ally (Winnicki dla). Nationalists wanted to greet President Trump with a picket line (Trump).

The aversion to the United States is to some extent a derivative of antagonism with the US allies - Israel and Ukraine. The leading issue is the claims to Jewish heirless property and the related so-called Act 447 (Winnicki o roszczeniach; Krzysztof Bosak: rzad), but this is only a small part of the entire body of problems arising from Polish-Jewish relations (e.g., accusing Poles of complicity in the Holocaust, participation of Jews in the communist apparatus). ${ }^{5}$ The Confederates warn against the influence of the Jewish lobby, for example, Braun said that "Today's ministers and bishops are at the Jewish press beck and call" (Konfederacja wzywa). The attitude of the national right wing towards Ukraine is also characterized by long-standing aversion. The historical conflict, which culminated in the Volhynian slaughter, is projected onto contemporary Ukrainian politics, suspected of expansionist attempts towards Poland. The Confederates believe that "ad hoc politics, often incompatible with our national interest, is prioritized over the memory of Polish martyrdom" (Marciniuk, 2019). Therefore, in their opinion, unconditional support for Ukraine is contrary to the Polish "raison d'État," although they do not question the role of the inde-

${ }^{5}$ Sowiński 2019; Konfederacja broni; Skandaliczny. Even the member of the liberal faction of the Confederacy J.W. Bartyzel protested against the excessively broad use of the term "anti-Semitism". Bartyzel 2019 
pendent Ukrainian state as a buffer separating Poland from Russia (Krzysztof Bosak: rzad).

However, the KWiN did not clearly formulate alternative "vectors" of Polish foreign policy. In principle, the Confederacy does not question Poland's membership in NATO (Krzysztof Bosak: rzad), although the party emphasizes the development of own defense capabilities (Zapałowski, 2019). Korwin-Mikke allowed for the possibility of a military alliance with Russia, but he came in for criticism even in his parent political camp (Korwin-Mikke: Polska; Korwin-Mikke: Obydwaj; Korwin-Mikke w studiu). Other Confederacy politicians speak of Russia without sentiment. "Russia is a large country, a country pursuing a brutal, arrogant policy, with which we have tense relations," said Bosak (Sasin). At the same time, however, the confrontational policy towards Russia was opposed, considering it unfavorable for Poland (Winnicki dla). "I do not see any reason why we should annoy our neighbor. It is in our interest to have peace and trade with all neighbors," stated Tuduj (Tuduj, 2019). Poland's participation in the Chinese New Silk Road program is also taken into account (Ziętek-Wielomska, 2019; Bartyzel, 2019; Wilk, 2019), but again the opinions are divided (Drozdowski, 2019a).

\section{Social base}

In the May elections to the European Parliament, the Confederates won 4.55\% of votes (Wybory do parlamentu). In the parliamentary elections in October, $1,256,953$ voters voted for the KWiN, which constituted $6.81 \%$ of votes (Wyniki wyborów). Importantly, crossing the election threshold resulted in strengthening the position of KWiN, as $8.3 \%$ of respondents expressed the will to vote for this party in November and in December - $12 \%$ ( $W$ nowym).

The KWiN electorate is based on young educated men from big cities. 9 percent of men and 4.1 percent of women voted for the Confederacy. Among people aged $18-29$, the Confederacy received as much as $20.2 \%$ of votes, the age group 30-39 (8.2\%) also voted above average, while not many votes were received from the older generation. In terms of occupations, the Confederates are most popular among students $(17.9 \%)$, business owners $(8.8 \%)$ and management $(8.1 \%)$, the average proportion of votes was cast among workers $(7.4 \%)$, the unemployed $(6.9 \%)$ as well as administration and service employees (6.6\%), and the lowest among farmers (3.4\%), old age and disability pensioners (1.1\%). The Confederacy's electorate is dominated by voters with higher $(43.6 \%)$ or secondary $(41.2 \%)$ education (Zaborowska 2019). In terms of geography, the KWiN achieved the highest results in the following districts: średzki (13.5\%), bieszczadzki (7.52\%), Stalowa Wola (7.10\%) and Rzeszów (7.09\%) (Wybory europejskie). 
The presidential election strengthened the position of the Confederacy. Under the conditions of sharp polarization, obtaining the result of $6.78 \%$ in the first round of the elections should be considered a success (for comparison most of the voters of the parliamentary Left handed over their votes to Rafał Trzaskowski). This success was even greater because Bosak's campaign was relatively cheap - it cost less than PLN 2 million (Bosak: $\dot{Z} y c z e$ ). Moreover, the Confederacy candidate managed to win over a significant proportion of young people, including first-time voters: $21.7 \%$ of voters aged 18-29.

As in the parliamentary elections, the average Bosak voter is a young (more than half are under 30$)$ male ( $2 / 3$ of the electorate) with secondary or higher education (84.9\%), studying (19.1\%) or working in services (18\%). Considering the cross-section of society, the KWiN candidate turned out to be the most popular among high school students and university students (20.4\%). He was also overrepresented in the circles of entrepreneurs $(8.5 \%)$, managerial staff $(8.4 \%)$, workers $(8.0 \%)$ and even unemployed (7.3\%) (Wyniki głosowania). In the spatial aspect, Bosak gained the greatest support - over 10\% — in the following districts: Łęczna (10.66), Rzeszów (10.18) and Rzeszów (10.02), and among the crews of sea-going vessels (19.51\%) (Wybory Prezydenta).

It is visible that the voters of KWiN and Bosak have a clear sociological profile. This is the strength of the formation as it ensures its cohesion, but at the same time, it is its weakness as it hinders further expansion. The Confederacy faces the difficult task of gaining a different electorate - in the first place PiS voters: older, less educated people, rather socially oriented. Without this, the Confederates will remain a party balancing on the verge of the election threshold.

\section{Conclusions}

The analysis of Confederate ideology and modus operandi reveals their multifaceted inconsistency. There are a number of contradictions, the most important of which are: $/ 1 /$ the contradiction between the traditionalist and the modernizing element (including - between the modern form and conservative content), $/ 2 /$ the contradiction between the conservative (conservative-liberal) and the national-democratic tradition, /3/ contradiction between native and "imported" patterns. From the rich ideological heritage of the Poland's right wing, the Confederates try to select elements /a/ common to the trends that co-create the KWiN, /b/ compatible with the contemporary social environment. Although consolidation is difficult, the plane of consensus is cultural Catholicism and economic liberalism. 
The success of KWiN is in line with the general Western trend of the rightwing backlash. The Polish mutation of this phenomenon, however, retains its specific character. Compared to the Western European new populist right, the traditionalist component in the Confederacy is stronger, while there is no social populism (characteristic of, for example, Front National or Sverigedemokraterna), and the issue of immigration is also of little importance (cf. Tomasiewicz 2019: 71-86). It seems that the Polish radical right is closer to the American model: Tea Party, Trumpizm, alt-right (cf. Anglin, 2016; Langman, 2011; Post, 2017).

\section{References}

\#Konfederacja proponuje wprowadzenie nowych zasad ws. podróży stużbowych!, (2019), https://www.facebook.com/watch/?v=362944301069536

\#KONFEDERACJA zarejestrowana jako partia polityczna!, (2019), https://twitter. com/KONFEDERACJA_/status/1154757013458640897

Anglin A. (2016), A Normie's Guide to the Alt-Right, https://dailystormer.red/a-normies-guide-to-the-alt-right/

A.P. (2017), KORWIN: Koalicja Odnowy Rzeczypospolitej Wolność i Nadzieja, W: R. Glajcar, A. Turska-Kawa, W. Wojtasik (red.), Leksykon polskich partii politycznych, Toruń: Adam Marszałek

Bala P. (2019), Demokracja to najgłupszy ustrój na świecie, https://konserwatyzm. $\mathrm{pl} /$ demokracja-to-najglupszy-ustroj-na-swiecie-mowi-pawel-bala-konfederacja-wrozmowie-z-pawlem-wyrzykowskim/

Baliszewski T. (2013), Przemystaw Holocher odchodzi z zarzadu Ruchu Narodowego, https://natemat.pl/74119,przemyslaw-holocher-odchodzi-z-zarzadu-ruchu-narodowego-przepraszam-tych-ktorzy-poczuli-sie-urazeni

Bartyzel J.W. (2019), Sam siebie definiuje jako liberat, choć zamiennie używam określeń ,,wolnościowiec” $i$,,libertarianin”, https://konserwatyzm.pl/sam-siebie-definiuje-jako-liberal-choc-zamiennie-uzywam-okreslen-wolnosciowiec-i-libertarianin/

Benecki R., Kasek L. (2020), Poland: Presidential election preview, https://think.ing. com/articles/poland-presidential-election-preview/

B.K.-G. (2017), Kongres Nowej Prawicy, W: R. Glajcar, A. Turska-Kawa, W. Wojtasik (red.), Leksykon polskich partii politycznych, Toruń: Adam Marszałek

Bosak K. (2019), Będziemy starannie monitorować polityke imigracyjna rzadu, https://kresy.pl/publicystyka/wywiady/krzysztof-bosak-dla-kresy-pl-bedziemy-starannie-monitorowac-polityke-imigracyjna-rzadu/

Bosak: „Media Narodowe miały ogromne znaczenie w sukcesie Konfederacji” (2019), https://medianarodowe.com/bosak-media-narodowe-mialy-ogromne-znacze nie-w-sukcesie-konfederacji-wideo/

Bosak: Wiara na stowa temu rzqdowi to czysta naiwność (2020), https://www.rmf24. 
pl/tylko-w-rmf24/poranna-rozmowa/news-bosak-wiara-na-slowa-temu-rzadowi-toczysta-naiwnosc,nId, 4582226

Bosak: Życzę Trzaskowskiemu, żeby został konserwatysta, wolnościowcem, polskim patriota, (2020), https://www.rp.pl/Wybory-prezydenckie-2020/200709754-BosakZycze-Trzaskowskiemu-zeby-zostal-konserwatysta-wolnosciowcem-polskim-patrio ta.html

Bryłka A. (2019), Postulaty współczesnych feministek sa wprost zaprzeczeniem tego, o co walczyty pierwsze emancypantki, Konserwatyzm.pl, $15 \mathrm{~V}$, https://konserwatyzm.pl/postulaty-wspolczesnych-feministek-sa-wprost-zaprzeczeniem-tego-oco-walczyly-pierwsze-emancypantki-mowi-anna-brylka-w-rozmowie-z-a-wielom skim/

B.S. (1996), Konserwatywno-Liberalna Partia Unia Polityki Realnej, W: Paszkiewicz K.A. (red.), Polskie partie polityczne. Charakterystyki, dokumenty, Wroclaw: Hector

B.S. (2000), Konserwatywno-Liberalna Partia Unia Polityki Realnej, W: Paszkiewicz K.A. (red.), Partie i koalicje polityczne III Rzeczypospolitej, Wrocław: Wydawnictwo Uniwersytetu Wrocławskiego

Cejrowski o medialnej ciszy wokół Konfederacji, (2019), https://medianarodowe.com/ cejrowski-o-ciszy-medialnej-wokol-konfederacji/

Cenzura: TVN pokazało komitety ogólnopolskie...prócz Konfederacji!, (2019), https://medianarodowe.com/cenzura-tvn-pokazalo-komitety-ogolnopolskie-proczkonfederacji/

Cwikła D. (2019), Czy to musi być przykry koniec Kai Godek?, https://medianarodowe.com/opinia-cwikla-czy-to-musi-byc-przykry-koniec-kai-godek/

„Czerwona kartka dla TVPiS”, (2019), https://medianarodowe.com/czerwona-kartkadla-tvpis-konfederacja/

Czuma B., Kaja Godek startuje do Parlamentu Europejskiego razem z narodowcami, Wirtualna Polska 2019, 28 I, https://wiadomosci.wp.pl/kaja-godek-startuje-doparlamentu-europejskiego-razem-z-narodowcami-6343349374052481a

Debata w TVP!, (2019), https://medianarodowe.com/debata-w-tvp-jacek-wilk-bylprzedstawicielem-konfederacji/

Dość skazywania ludzi bez dowodów!, (2019), https://medianarodowe.com/dosc-ska zywania-ludzi-bez-dowodow-projekt-ustawy-ws-malego-swiadka-koronnego/

Drozdowski K. (2019a), Obecnie Bruksela to stajnia Augiasza, Konserwatyzm.pl, $1 \mathrm{~V}$, https://konserwatyzm.pl/obecnie-bruksela-to-stajnia-augiasza-mowi-krzysztof -drozdowski-lider-listy-konfederacja-w-okregu-kujawsko-pomorskim-w-rozmowiez-p-bala/

Drozdowski K. (2019b), Unia Europejska — miłość i nienawiść, https://medianarodowe.com/unia-europejska-milosc-nienawisc/

Działacze Kukiz'15 przechodza do Konfederacji, (2019), https://medianarodowe.com/ dzialacze-kukiz15-przechodza-do-konfederacji/;

Dziambor: Konfederacja może poprzé stuszne projekty PiS, (2019), https://medianarodowe.com/dziambor-konfederacja-moze-poprzec-sluszne-projekty-pis/

Dziambor A. (2019), Celem Konfederacji jest wprowadzenie silnej reprezentacji, która będzie bezkompromisowo walczyła o nasze narodowe racje, https://kon serwatyzm.pl/celem-konfederacji-jest-wprowadzenie-silnej-reprezentacji-ktora-bed 
zie-bezkompromisowo-walczyla-o-nasze-narodowe-racje-z-arturem-dziamboremrozmawia-a-wielomski/

Dziesiątki tysięcy Polaków w Warszawie przeciwko ustawie 447!, (2019), http://naro dowcy.net/tysiace-ludzi-na-marszu-przeciwko-ustawie-447/

Dzisiaj dwie duże debaty, Polsat i TVN, (2019), https://medianarodowe.com/dzisiajdwie-duze-debaty-polsat-i-tvn-beda-bosak-i-winnicki/

Ekonomiczny ,ekspert” Konfederacji za ukraińska imigracja, (2019), http://www. autonom.pl/?p=28104

Federacja Jakubiak-Liroy kończy działalność?, (2019), https://medianarodowe.com/ federacja-jakubiak-liroy-konczy-dzialalnosc-jakubiak-chce-startowac-z-list-pis/;

Fenomenalny wykład Mentzena, (2019), https://medianarodowe.com/fenomenalnywyklad-mentzena-nie-chcemy-zydow-homoseksualistow-aborcji-podatkow-i-uniieuropejskiej/

„,Głos na Liroya to głos na PO”, (2019), https://medianarodowe.com/glos-na-liroya-toglos-na-po-robert-winnicki-komentuje/

GodekKaja (2019a), https://twitter.com/GodekKaja/status/1131514666033848321

GodekKaja (2019b), https://twitter.com/GodekKaja/status/1131935757109743616 ;

Index of /file/fb_onr/, (1984), https://wlstorage.net/file/fb_onr/

Kalinowski (2019a), https://twitter.com/kalinowski_/status/1114489335879958528

Kalinowski T. (2019b), Antysystem musi budować sitę społeczna, polityczna, medialna i finansowa, https://medianarodowe.com/kalinowski-analizuje-antysystem-musi -budowac-sile-spoleczna-polityczna-medialna-i-finansowa/

Kampania kandydata Konfederacji hitem w sieci!, (2019), https://medianarodowe. com/kampania-kandydata-konfederacji-hitem-w-sieci-wyborcy-z-podlasia-wzielisprawy-w-swoje-rece/

Kandydat Kukiz'15 rezygnuje i popiera Konfederacje, (2019), https://medianarodowe. com/kandydat-kukiz15-rezygnuje-popiera-konfederacje/

Kandydatka ,,Konfederacji”: startuje, bo zawsze byty mi bliskie poglady lewicowe, (2019), http://xportal.pl/?p=35392

Kolejna blokada prawicowych stron na Facebooku tuż przed wyborami, (2019), https://medianarodowe.com/kolejna-blokada-prawicowych-stron-na-facebooku-tuzprzed-wyborami-lacznie-3-mln-polubien/

Kolejna partia dołacza do Konfederacji, (2019), http://narodowcy.net/kolejna-partiadolacza-do-konfederacji-zajma-sie-tematyka-pro-life/

Konfederacja broni mieszkańców Pruchnika, (2019), https://medianarodowe.com/ konfederacja-broni-mieszkancow-pruchnika/

Konfederacja i Kukiz'15 negocjuja wspólny start w wyborach, (2019), https://kresy.pl/ wydarzenia/konfederacja-i-kukiz15-negocjuja-wspolny-start-w-wyborach/

Konfederacja KORWIN Braun Liroy Narodowcy taczy sity!, (2019), https://medianarodowe.com/konfederacja-korwin-braun-liroy-narodowcy-laczy-sily-wideo/

Konfederacja KORWiN Braun Liroy Narodowcy powiększa się o środowiska kresowe, (2019), http://narodowcy.net/konfederacja-korwin-braun-liroy-narodowcypowieksza-sie-o-srodowiska-kresowe/

Konfederacja: Nie pozwolimy ubliżać polskim rolnikom, (2019), http://narodowcy.net/ konfederacja-nie-pozwolimy-ublizac-polskim-rolnikom/

Konfederacja obiecuje wprowadzenie ustawy anty-LGBT, (2019), https://kresy.pl/ 
wydarzenia/polska/konfederacja-obiecuje-wprowadzenie-ustawy-anty-lgbt/

Konfederacja odpowiada PiS, (2019), https://medianarodowe.com/sejmowa-konferencja-prasowa-liderow-konfederacji/

Konfederacja ogólnopolskim komitetem wyborczym!, (2019), https://medianarodowe. com/konfederacja-ogolnopolskim-komitetem-wyborczym-szybciej-niz-koalicjaobywatelska/

Konfederacja ostatecznie z jednym kołem poselskim, (2019), https://medianarodowe. com/konfederacja-ostatecznie-z-jednym-kolem-poselskim/

Konfederacja ostro o Emilewicz, (2019), https://medianarodowe.com/konfederacjaostro-o-emilewicz-to-jest-teczowy-pis/

Konfederacja ostro o wpisach Mosbacher, (2019), https://medianarodowe.com/kon federacja-ostro-o-mosbacher/

Konfederacja składa wniosek o odwołanie Adama Bodnara, (2019), https://medianar odowe.com/konfederacja-sklada-wniosek-o-odwolanie-adama-bodnara/

Konfederacja: Wyprowadzimy Polskę z UE pozostajac w strefie Schengen i EOG, (2019), https://medianarodowe.com/polexit-pozostajac-strefie-schengen/

Konfederacja wzywa rząd do ujawnienia rozmów ws. Roszczeń, (2019), https://medianarodowe.com/konfederacja-sklada-interpelacje-ws-roszczen/

Konfederacja zaprezentowała tezy programowe na wybory do parlamentu, (2019), https://kresy.pl/wydarzenia/polska/konfederacja-zaprezentowala-tezy-programowena-wybory-do-parlamentu-video/

Konfederacja zapowiada program na jesienne wybory, (2019), https://medianarodowe.com/konfederacja-zapowiada-program-na-jesienne-wybory/

Konfederacja zorganizuje prawybory prezydenckie, (2019), https://kresy.pl/wydarze nia/polityka/konfederacja-zorganizuje-prawybory-prezydenckie/

Konwencja Konfederacji, (2019), https://medianarodowe.com/konwencja-konfederacjipolacy-beda-elita/

Konwencja wyborcza Konfederacji w Warszawie, (2019), http://narodowcy.net/kon wencja-wyborcza-konfederacji-polexit/

Korwin, Braun czy Bosak?, (2019), https://kresy.pl/publicystyka/korwin-braun-czybosak-wszystko-co-nalezy-wiedziec-o-prawyborach-prezydenckich-w-konfederacji/

Korwin-Mikke J. (2012), Narodowy socjalizm czy konserwatyzm?, http://www. fronda.pl/news/czytaj/tytul/korwin-mikke:_narodowy_socjalizm_czy_konserwatyzm 23262

Korwin-Mikke: Obydwaj z Kornelem Morawieckim nawotywaliśmy do realizmu w stosunkach z Rosja, (2019), https://kresy.pl/wydarzenia/korwin-mikke-obydwajz-kornelem-morawieckim-nawolywalismy-do-realizmu-w-stosunkach-z-rosja/

Korwin-Mikke: PiS jest amerykańska agentura, (2019), https://kresy.pl/wydarzenia/ polityka/korwin-mikke-pis-jest-amerykanska-agentura/;

Korwin-Mikke: PiS zależy na wojskach USA w Polsce, więc sa gotowi spetniać niemal dowolne życzenia, (2019), https://kresy.pl/wydarzenia/korwin-mikke-pis-zalezy-nawojskach-usa-w-polsce-wiec-sa-gotowi-spelniac-niemal-dowolne-zyczenia/

Korwin-Mikke: Polska powinna zawrzé́ sojusz dwustronny z USA, a jeśli to niemożliwe wspótpracować z Rosja, (2019), https://kresy.pl/wydarzenia/korwinmikke-polska-powinna-zawrzec-sojusz-dwustronny-z-usa-a-jesli-to-niemozliwe- 
wspolpracowac-z-rosja/

Korwin-Mikke w studiu Mediów Narodowych, (2019), https://medianarodowe.com/ korwin-mikke-w-studiu-mediow-narodowych-dlaczego-nie-jestem-antyrosyjskiwideo/

Korwin ostro o LGBT, (2019), https://medianarodowe.com/korwin-ostro-o-lgbt-trzebawyrznac-te-wszystkie-elity-ktore-popieraja-zboczenia/

Krystyna Pawłowicz w Konfederacji?, (2019), https://medianarodowe.com/krystynapawlowicz-w-konfederacji-jakubiak-przyjalbym-pania-posel-do-swojego-ugrupow ania/

Krzysztof Bosak: jestem pewien, że wśród wyborców Konfederacji sq homoseksualiści, (2019), https://wiadomosci.radiozet.pl/Polityka/Wybory-prezydenckie-2020/ Krzysztof-Bosak-jestem-pewien-ze-wsrod-wyborcow-Konfederacji-sa-homoseksualisci-WYWIAD

Krzysztof Bosak: musimy postawić na gospodarke wodna, (2019), https://www.portalsamorzadowy.pl/polityka-i-spoleczenstwo/krzysztof-bosak-musimy-postawic-nagospodarke-wodna, 188397.html

Krzysztof Bosak podsumowuje konwencje Konfederacji, (2019), https://medianarodowe.com/krzysztof-bosak-podsumowuje-konwencje-konfederacji-wideo/

Krzysztof Bosak: rząd PiS ,występuje jako agent interesów amerykańskich”, (2019), https://kresy.pl/wydarzenia/polityka/krzysztof-bosak-rzad-pis-wystepuje-jako-agent -interesow-amerykanskich/

K.Z. (2017), Liga Polskich Rodzin, W: R. Glajcar, A. Turska-Kawa, W. Wojtasik (red.), Leksykon polskich partii politycznych, Toruń: Adam Marszałek

Langman L. (2011), Cycles of Contention: The Rise and Fall of the Tea Party, "Critical Sociology", $\mathrm{nr}$ 4, s. 469-494

Lewicki S. (2019), Konfederacja po wyborach, https://konserwatyzm.pl/lewicki-konfederacja-po-wyborach/

Liderzy Konfederacji żadaja wyjaśnień w sprawie izraelskiego systemu Pegasus, (2019), https://medianarodowe.com/liderzy-konfederacji-zadaja-wyjasnien-w-sprawie-izraelskiego-systemu-pegasus/

Liroy napisat list do KRRiT, (2019), https://medianarodowe.com/liroy-napisal-list-dokrrit/

Lista kandydatów oficjalnie popieranych przez Ruch Narodowy, (2015), https://ruchnarodowy.net/lista-kandydatow-oficjalnie-popieranych-przez-ruch-narodowy/

Łobodzinski W. (2019), Dzisiejsza młodzież jest pusta, https://strajk.eu/dzisiejszamlodziez-jest-pusta-wywiad-z-bylym-wszechpolakiem/

Marciniuk A. (2019), PiS ulegnie Stanom Zjednoczonym w sprawie zwrotu mienia bezspadkowego, https://konserwatyzm.pl/pis-ulegnie-stanom-zjednoczonym-wsprawie-zwrotu-mienia-bezspadkowego-mowi-agnieszka-marciniuk/

Marsz Suwerenności przeszedt ulicami Warszawy, (2019), http://narodowcy.net/marsz -suwerennosci-przeszedl-ulicami-warszawypolexit/

Mentzen S. (2019), Konserwatyści maja mnie za libertarianina a libertarianie za zamordystę, https://konserwatyzm.pl/konserwatysci-maja-mnie-za-libertarianina-a -libertarianie-za-zamordyste-mowi-slawomir-mentzen-konfederacja-w-rozmowie-zadamem-wielomskim/

Minister rolnictwa ujawnia niewydolność ARiMR, (2019), https://kresy.pl/wydarze 
nia/minister-rolnictwa-ujawnia-niewydolnosc-arimr-chora-instytucja-konfederacjaujawnia-nagranie-video/

Młodzież Wszechpolska pocięła flage Unii Europejskiej na Marszu Suwerenności, (2019), http://narodowcy.net/mlodziez-wszechpolska-pociela-flage-unii-europejskiej -na-marszu-suwerennosci/

Młodzież Wszechpolska: zerwanie z LPR jest dla nas korzystne, (2006), https:// wiadomosci.wp.pl/mlodziez-wszechpolska-zerwanie-z-lpr-jest-dla-nas-korzystne6037396982243969a?src01=f1e45

Nacjonaliści w sejmie — Ruch Narodowy wprowadza pięciu posłów, (2019), http:// narodowcy.net/nacjonalisci-w-sejmie-ruch-narodowy-wprowadza-pieciu-poslow/

Narodowy Kongres Kobiet, (2019), https://narodowcy.net/narodowy-kongres-kobietchcemy-zachowywac-szacunek-dla-katolickiej-tradycji-naszego-narodu/

Naszym wrogiem jest tzw. ,prawica”, (2019), http://narodowcy.net/naszym-wrogiemjest-tzw-prawica-bosak-na-marszu-suwerennosci/

Nowak P. (2020), „Faszysta”- ktoś podpisat kampanijny samochodzik Krzysztofa Bosaka, https://strajk.eu/faszysta-ktos-podpisal-kampanijny-samochodzik-krzysztofa-bosaka/

Nowy poset $w$ Konfederacji!, (2019), https://medianarodowe.com/nowy-posel-w-kon federacji-to-jedyna-sila-ktora-odwaznie-stoi-po-stronie-wartosci-rodziny-i-dzieci/

Nowy spot Konfederacji hitem w sieci, (2019), https://medianarodowe.com/hit-nowyspot-konfederacji-hitem-w-sieci-tak-sie-robi-kampanie-wideo/

Partia_KORWiN (2019), https://twitter.com/Partia_KORWiN/status/10988946669703 41376/photo/1

Pierwsze obrady koła poselskiego Konfederacji, (2019), https://medianarodowe.com/ pierwsze-obrady-kola-poselskiego-konfederacji-kulesza-przewodniczacym/

Piotr Szlachtowicz o zachowaniu Berkowicza, (2019), https://medianarodowe.com/ szlachtowicz-o-zachowaniu-berkowicza-to-jest-glupota/

Poczatek kampanii z przytupem, (2019), https://medianarodowe.com/poczatek-kampanii-z-przytupem-kandydat-konfederacji-pozywa-wyborcza/

Pokora-Kalinowska M. (2019), Konfederacja oddała „,szóstkę” rolnikom, https:// www.farmer.pl/finanse/podatki-rachunkowosc/konfederacja-oddala-szostke-rolnikom, 88295.html

Polityk Konfederacji: W drugiej turze będzie trzeba zagłosować na Trzaskowskiego, (2020), https://www.tvp.info/48498312/polityk-konfederacji-w-drugiej-turze-bedzie -trzeba-zaglosowac-na-trzaskowskiego

„Polska dla Ciebie”, (2019), https://kresy.pl/wydarzenia/polska-dla-ciebie-konfedera cja-przestawia-swoja-piatke-video-foto/

Polska nie wstała z kolan, a tylko zmieniła klęcznik z UE na USA, (2019), https:// medianarodowe.com/polska-nie-wstala-z-kolan-a-tylko-zmienila-klecznik-z-ue-nausa-bosak-ostro-o-pis/

Poset Konfederacji dołaczył do zespołu ds. równouprawnienia LGBT, (2019), http:// wiadomosci.gazeta.pl/wiadomosci/7,114884,25430323,posel-konfederacji-dolaczyldo-zespolu-ds-rownouprawnienia.html

Poset Robert Majka, wybrany z list Kukiz'15, dołacza do koła Konfederacji!, (2019), https://www.facebook.com/jkm.wolnosc/videos/543142192878790/ 
Post Ch. (2017), The roots of Trumpism, "Cultural Dynamics", nr 1-2, s. 100-116 Powstaje nowe prawicowe ugrupowanie pod patronatem Mariana Kowalskiego Narodowcy RP!, (2015), https://polskaniepodlegla.pl/kraj-swiat/item/4312-powstaje -nowe-prawicowe-ugrupowanie-pod-patronatem-mariana-kowalskiego-narodow cy-rp

Pracownicy TVP przed debata chcieli zabrać Jackowi Wilkowi polska flagę, (2019), https://kresy.pl/wydarzenia/regiony/polska-regiony/pracownicy-tvp-przed-debatachcieli-zabrac-jackowi-wilkowi-polska-flage-video/

Prezes Ruchu Narodowego dla DoRzeczy, (2019), https://medianarodowe.com/prezesrn-dla-dorzeczy-demontaz-unii-mozliwy/;

Prezes Trybunatu broni aborcji, (2019), https://medianarodowe.com/prezes-trybunalubroni-aborcji-wawer-pis-to-aborcjonisci-w-maskach-katolikow/

Prof. Wielomski o Konfederacji, (2019), https://kresy.pl/publicystyka/prof-wielomski -o-konfederacji-liberalizm-kosmopolityczny-przeksztalcil-sie-w-liberalizm-polski/

R. Winnicki o wynikach Konfederacji, (2019), https://medianarodowe.com/winnicki-owynikach-konfederacji-wideo/

Reorganizacja struktur RN po odejściu grupy posłów, (2016), https://ruchnarodowy. net/reorganizacja-struktur-rn-odejsciu-grupy-poslow/

Robert Winnicki dzisiaj w „Przedwyborczym Q\&A”, (2019), https://medianarodowe. com/robert-winnicki-dzisiaj-w-przedwyborczym-qa-onet-godz-1900/

Rozłam w Konfederacji, (2019), https://kresy.pl/wydarzenia/polityka/rozlam-w-konfederacji/.

Ruch Narodowy, (b.d.), https://www.wikiwand.com/pl/Wikipedysta:Milek1243/brud nopis

Ruch Narodowy $i$ Wolność utworzyty „eurosceptyczna” koalicję w wyborach do PE, (2018), https://www.radiomaryja.pl/informacje/ruch-narodowy-i-wolnosc-utworzyly -eurosceptyczna-koalicje-w-wyborach-do-pe/

Rzeszów przeciwko roszczeniom żydowskim, (2019), http://narodowcy.net/rzeszowprzeciwko-roszczeniom-zydowskim-protest-nie-dla-ustawy-447/

Sajna C. (2019), Chyba rzeczywiście mam wiele wspólnego z Wolterem, https://kon serwatyzm.pl/chyba-rzeczywiscie-mam-wiele-wspolnego-z-wolterem-mowi-cy prian-sajna-w-rozmowie-z-adamem-wielomskim/

Sasin: Konfederacja jest ugrupowaniem skrajnie prorosyjskim, (2019), https://kresy. $\mathrm{pl} /$ wydarzenia/sasin-konfederacja-jest-ugrupowaniem-skrajnie-prorosyjskim/

Sensacyjna wiadomość - Jakubiak dołaczy do Konfederacji, (2019), https://medianarodowe.com/sensacyjna-wiadomosc-jakubiak-dolaczy-do-konfederacji-musimylaczyc-sily/

Setki Bydgoszczan sprzeciwiło się Paradzie Równości, (2019), http://narodowcy.net/ paradarownosci-setki-bydgoszczan-sprzeciwilo-sie-paradzie-rownosci/

Sitnicka D. (2020), Bosak kandydatem Konfederacji na prezydenta, https://oko.press/ krzysztof-bosak-kandydatem-konfederacji-na-prezydenta/

Skandal! KJ nie chce Konfederacji $w$ debacie, (2019), https://medianarodowe.com/ skandal-kj-nie-chce-konfederacji-w-debacie-zapraszaja-znajomych/

Skandaliczny atak na Polske, (2019), https://medianarodowe.com/skandaliczny-atak-na -polske-francuska-senator-o-wrodzonym-antysemityzmie-polakow/ 
Skupień A. (2019), Zjednoczona Prawica nie zrobiła nic, aby zachęcić Polaków do powrotu do ojczyzny, (2019), https://konserwatyzm.pl/zjednoczona-prawica-niezrobila-nic-aby-zachecic-polakow-do-powrotu-do-ojczyzny-mowi-andrzej-skupienkonfederacja-w-rozmowie-z-adamem-wielomskim/

Smuniewski K. (2019), Nie jestem liberałem czy wolnościowcem, Konserwatyzm. pl 2019, 9 X, https://konserwatyzm.pl/nie-jestem-liberalem-czy-wolnosciowcemmowi-konrad-smuniewski/

Sowiński W. (2019), Szukanie podtekstów rasistowskich, szczególnie $w$ stosunku do narodu żydowskiego, osiagnęło w Polsce granice absurdu, https://konserwatyzm. $\mathrm{pl} /$ szukanie-podtekstow-rasistowskich-szczegolnie-w-stosunku-do-narodu-zydowskiego-osiagnelo-w-polsce-granice-absurdu-z-wieslawem-sowinskim-rozmawiaa-wielomski/

Szczecin: Konfederacja zbiera podpisy pod zmiana nazwy placu im. Adamowicza, (2019), http://narodowcy.net/szczecin-konfederacja-zbiera-podpisy-pod-zmiana-nazwy-placu-im-adamowicza/

Szok! Konfederacja: ostatnie posiedzenie Sejmu było nielegalne, (2019), https:// medianarodowe.com/szok-konfederacja-ostatnie-posiedzenie-sejmu-bylo-nielegalne -wideo/

Szydził z Jana Pawła II, teraz bryluje u boku Marka Jakubiaka, (2019), https://strajk. eu/szydzil-z-jana-pawla-ii-terazi-bryluje-u-boku-marka-jakubiaka/

Szymanik G. (2012), Skini, policja $i$ antyfaszyści. Konflikt trwa od lat, https://war szawa.wyborcza.pl/warszawa/56,34862,10624511,Skini__policja_i_antyfaszysci

Konflikt_trwa_od_lat.html

Szymański K. (2019), Powrót na pozycje katolickie, http://narodowcy.net/krzysztofszymanski-powrot-na-pozycje-katolickie/

Takiej kampanii jeszcze nie było!, (2019), https://medianarodowe.com/takiej-kampanii -jeszcze-nie-bylo-konfederacja-oglasza-1000-plus-dla-kazdego-pracujacego-polaka/

Telewizja publiczna kłamie, (2019), https://kresy.pl/wydarzenia/telewizja-publicznaklamie-konfederacja-sklada-pozew-w-trybie-wyborczym-przeciwko-tvp-video/

Tomasiewicz J. (2002), Powrót Ligi, „Sprawy Polityczne”, nr 13-14, s. 39-43

Tomasiewicz J. (2003), Ugrupowania neoendeckie w Trzeciej Rzeczypospolitej, Toruń: Adam Marszałek.

Tomasiewicz J. (2010), Ucieczka od wolności? Prawicowy radykalizm na przykładzie Obozu Narodowo-Radykalnego, ,Zeszyty Naukowe Wyższej Szkoły Bankowości i Finansów w Bielsku-Białej”, nr 3, s. 71-83

Tomasiewicz J. (2019), Reakcja. Prawicowy populizm jako odpowiedź na wyzwanie migracji $i$ wielokulturowości, W: Migranci i mniejszości jako swoi i obcy w przestrzeni polityczno-społecznej. Red. A. Adamczyk, A. Sakson, C. Trosiak. Poznań: Wydawnictwo Naukowe Wydziału Nauk Politycznych i Dziennikarstwa, s. 71-86

Trela Z. (2019), Nacjonalizm przedkłada interes własnego narodu nad interesy innych narodów, https://konserwatyzm.pl/nacjonalizm-przedklada-interes-wlasnego-narodu-nad-interesy-innych-narodow-mowi-zuzanna-trela-konfederacja-w-rozmowie-z-adamem-wielomskim/

Trump zapowiada przyjazd do Polski, (2019), https://kresy.pl/wydarzenia/trump-zapowiada-przyjazd-do-polski-ruch-narodowy-powita-go-pikieta-nie-dla-roszczen/ 
Trzy komitety w ciagu jednej kampanii, (2019), https://medianarodowe.com/trzy-ko mitety-w-ciagu-jednej-kampanii-kaja-godek-kolejny-raz-zmienia-decyzje/

Tuduj K. (2019), Jesteśmy katolicko-narodowym wyrzutem sumienia dla PISu, https://konserwatyzm.pl/jestesmy-katolicko-narodowym-wyrzutem-sumienia-dlapisu-mowi-krzysztof-tuduj/

Unia Polityki Realnej, (1991), W: Waszkiewicz J. (red.), Partie i ugrupowania polityczne. Vademecum, J., Warszawa: Polska Agencja Prasowa

W nowym sondażu pracowni wzrost poparcia dla mniejszych partii, (2019), https:// kresy.pl/wydarzenia/polityka/w-nowym-sondazu-wzrost-poparcia-dla-mniejszychpartii/

W Sejmie powstało koło poselskie koalicji Konfederacja, (2019), http://narodowcy. net/pilne-w-sejmie-powstalo-kolo-poselskie-koalicji-konfederacja/;

Warcholiński A., Tomanek P. (2020), „Przebojowy”, ,przyciaga”, „, nie ma innego kandydata dla młodej osoby", https://tvn24.pl/wybory-prezydenckie-2020/wybory -prezydenckie-2020-wyborcy-krzysztofa-bosaka-na-kogo-zaglosuja-w-2-turze-wyborow-4626549

Wawer M. (2019), Bluźnierstwo powinno być ścigane prawnie, a przede wszystkim powinno być potępione przez wszystkich kulturalnych ludzi, https://konserwa tyzm.pl/bluznierstwo-powinno-byc-scigane-prawnie-a-przede-wszystkim-powinno -byc-potepione-przez-wszystkich-kulturalnych-ludzi-mowi-mec-michale-wawer-wrozmowie-z-a-wielomskim/

Wiceprezes Ruchu Narodowego liderem listy Konfederacji w okręgu 13, (2019), https://medianarodowe.com/wiceprezes-ruchu-narodowego-jedynka-okreg-zachodniopomorskie/

Wieczorek A. (2019), Historia to nie mrzonki, mrzonkami sq opowieści o końcu historii, https://konserwatyzm.pl/historia-to-nie-mrzonki-mrzonkami-sa-opowiesci -o-koncu-historii-mowi-antoni-wieczorek-konfederacja-w-rozmowie-z-adamemwielomskim/

Wielomski A. (2019a), Konfederacja świadomie musi przyjąć postawę antyrzadowa, akcentować punkty niezgodności z PiS-em, https://konserwatyzm.pl/konfederacja -swiadomie-musi-przyjac-postawe-antyrzadowa-akcentowac-punkty-niezgodnosciz-pis-em-mowi-adam-wielomski-w-rozmowie-z-markiem-trojanem-kresy-pl/

Wielomski A. (2019b), Liberalizm kosmopolityczny a liberalizm polski, https://kon serwatyzm.pl/wielomski-liberalizm-kosmopolityczny-a-liberalizm-polski/

Wielomski A. (2019c), Penelizacja [sic] homoseksualizmu?, https://konserwatyzm.pl/ wielomski-penelizacja-homoseksualizmu/

Wielomski A. (2019d), Proponuję, aby Konfederacja samookreślata się mianem „,narodowych liberatów”, https://konserwatyzm.pl/proponuje-aby-konfederacjasamookreslala-sie-mianem-narodowych-liberalow/

Wilk J. (2019d), Polskie prawo jest dyktowane w obcych ambasadach, nowelizacje ustaw sa pisane w tajnej siedzibie Mosadu, https://konserwatyzm.pl/polskie-prawo-jest-dyktowane-w-obcych-ambasadach-nowelizacje-ustaw-sa-pisane-w-tajnejsiedzibie-mosadu-mowi-jacek-wilk-w-rozmowie-z-a-wielomskim/

Winnicki dla Kresy.pl: Możemy skończyć jak Kurdowie, (2019), https://kresy.pl/publi cystyka/wywiady/winnicki-dla-kresy-pl-mozemy-skonczyc-jak-kurdowie/ 
Winnicki o roszczeniach żydowskich, (2018), https://kresy.pl/wydarzenia/winnicki-o -roszczeniach-zydowskich-msz-przyznaje-ze-polske-wywierany-nacisk-ze-stronyrzadow-usa-izraela/

Winnicki o słowach Gowina, (2019), https://kresy.pl/wydarzenia/winnicki-o-slowachgowina-trzeba-zatrzymac-to-szalenstwo/

Winnicki o warunkach wspótpracy Konfederacji z PiS, (2019), https://kresy.pl/wyda rzenia/polityka/winnicki-o-warunkach-wspolpracy-konfederacji-z-pis/

Winnicki odpowiada Schetynie, (2019), https://medianarodowe.com/winnicki-odpo wiada-schetynie-nie-dla-koalicji-z-aferzystami/

Winnicki ostro o Sakiewiczu: „To regularny manipulator”, (2019), https://medianarodowe.com/winnicki-ostro-o-sakiewiczu-to-regularny-manipulator-bedzie-proces/

Winnicki ostro: „Polacy musza powstrzymać towarzyszy Biedronia i Czarzastego”, (2019), https://medianarodowe.com/winnicki-trzeba-powstrzymac-towarzyszy-cza rzastego/

Winnicki R. (2012), Dziecinada, http://rs.nowyekran.pl/post/72000,robert-winnickidziecinada

Wiosenny wiatr zrywa flagi Unii Europejskiej, (2019), https://www.facebook.com/ events/1312463385596724/

Wybory do Parlamentu Europejskiego 2019, (2019), https://wybory.gov.pl/pe2019/pl/ wyniki/pl

Wybory europejskie 2019: Konfederacja, (2019), http://www.wyborynamapie.pl/ euro2019/konfederacja.html

Wybory Prezydenta Rzeczypospolitej Polskiej 2020 (I tura), (2020), https://wybory. gov.pl/prezydent20200628/pl/dane_w_arkuszach

Wyniki głosowania, (2020), https://tvn24.pl/wybory-prezydenckie-2020/wyniki-sonda zowe-pierwsza-tura

Wyniki wyborów 2019 do Sejmu RP, (2019), https://wybory.gov.pl/sejmsenat2019/pl/ wyniki/sejm/pl

Wystartowała "KORONA” Grzegorza Brauna, czyli tradycjonalistyczne skrzydło Konfederacji, (2019), http://narodowcy.net/wystartowala-korona-grzegorza-brauna -czyli-tradycjonalistyczne-skrzydlo-konfederacji/

Zaborowska M. (2019), Wyniki wyborów: Jak głosy rozkładały się wedtug wieku, ptci, wyksztatcenia wyborców?, https://www.rmf24.pl/raporty/raport-wybory-par lamentarne-2019-fakty/najnowsze/news-wyniki-wyborow-jak-glosy-rozkladaly-siewedlug-wieku-plci-wy,nId,3276136

Zapałowski A. (2019), Pod względem wojskowym Rosja może swobodnie przeprowadzić operację przeciwko Polsce, https://konserwatyzm.pl/pod-wzgledem-woj skowym-rosja-moze-swobodnie-przeprowadzic-operacje-przeciwko-polsce-z-profandrzejem-zapalowskim-rozmawiaja-p-bala-i-a-wielomski/

Ziemkiewicz o niedzielnych wyborach, (2019), https://medianarodowe.com/ziemkie wicz-o-niedzielnych-wyborach-to-byla-niepowtarzalna-okazja-dla-konfederacji wideo/

Ziętek-Wielomska M., W „bloku masońskim” zawsze będziemy pariasami, gdyż jako Stowianie i katolicy stoimy na samym dnie, (2019), https://konserwatyzm.pl/wbloku-masonskim-zawsze-bedziemy-pariasami-gdyz-jako-slowianie-i-katolicy-stoimy-na-samym-dnie-mowi-magdalena-zietek-wielomska/ 
Jarosław Tomasiewicz: professor of University of Silesia in Katowice, employee of the Institute of History at the University of Silesia in Katowice.

$\mathrm{He}$ is a researcher of extremism and political violence. Some of his publications: „Ugrupowania neoendeckie w Trzeciej Rzeczpospolitej” (2003), „Naprawa czy zniszczenie demokracji?” (2012), „W kierunku nacjokracji” (2019). 